\title{
衛星画像を利用した都市域の不浸透面積率の推定
}

\author{
出口近士**杉尾 哲*
}

\section{Evaluating the Percentages of Impervious Area in Urban Area by Using Satellite Imagery}

Chikashi DEGUCHI ${ }^{*}$, Satoru SUGIO*

\begin{abstract}
This paper deals with the estimation for the percentage of impervious area by land-use categories classified from the satellite remote sensing imagery. The test area is KOMATU watershed, $4.64 \mathrm{~km}^{2}$, located in MIYAZAKI city. The area is divided into 14 zones for the estimation.

The percentages are also manually interpreted from aerial photographs observed in 1962 , 1966, 1973, 1983, and 1987. Then, these results are compared each other to check the accuracy of estimation.

From this investigation, the followings are clarified;

1) The overall percentages of impervious area in the whole test area change rapidly from $42 \%$ to $77 \%$ in the observed terms of aerial photographs.

2) The manually interpreted percentages from the aerial photograph contain about $10 \%$ error caused by the misjudgment.

3) High multiple-correlation coefficients are obtained between the percentages derived from the aerial photograph and one from the satellite imagery; 0.74 for LANDSAT-MSS, 0.81 for MOSMESSR and 0.91 for SPOT-HRV.

4) The discrepancies between them are $16 \%$ for LANDSAT-MSS, $19 \%$ for MOS-MESSR, $13 \%$ for SPOT-HRV in the worst sub-area and less then $10 \%$ except for the zones where contain the error caused by the misjudgment of aerial photograph and the geometric error of imagery.

From these results, it is confirmed that the satellite imagery is useful for the evaluation of groundwater recharge.
\end{abstract}

Key words: groundwater recharge, percentage of impervious area, satellite imagery

\footnotetext{
* 宮崎大学工学部土木環境工学科

Department of Civil and Environmental Engineering, Faculty of Engineering, Miyazaki University
} 


\section{1.はじめに}

宅地開発などの土地利用変化は、緑地の減少や雨 水排水網の整備あるいは人工物の構築による不浸透 域の拡大などに伴う地下水かん養量の減少などを通 じて、都市水文システムを変容させる。虫明ら(1990) は、都市流出の立場から、流域の開発を、植生の除 去ならびに表土の置換と輾圧、および不浸透域の拡 大、すなわち土地被覆条件と表層土層の変化として 捉え、このうち土地被覆条件は、森林の有無および 不浸透域の割合として表現できるとしている。また 都市域における地下水流動モデルでは、降雨量は浸 透域と不浸透域の面積比率で分配され、これらがモ デルの入力值となる。したがって、水循環システム における地下水かん養に関わる諸問題を取り扱う場 合、土地被覆情報の入手が不可欠となる。

従来、これらの土地被覆情報は、主として航空写 真の判読による万法で実施されてきており(新井ら、 1987)、現在では航空写真の判読の自動化も行われ ている(Draper \& Rao、1986)。しかしながら、こ れらの方法は労力や費用がかかるので、土地の改変 が少ない地域では、一度調査を実施すれば、その後 にわたってその調査結果をそのまま利用することが 多い。しかし都市近郊では、宅地が造成されたり、 建築物、道路、駐車場などが築造されるなど地表面 や土地利用の改変が急速に進むため、モデルの入力 変数である土地被覆情報も適宜、更新する必要が生 じる。

近年、これらの地表面の土地被覆情報の有効な収 集方法として、人工衛星からのリモートセンシング が利用されてきている。受動型の画像は、太陽光に よる電磁波の地表面の反射強度をいくつかの波長帯 域(バンド)に分けて捕捉したものであり、ハンド毎 の反射強度が数值として磁気テープ(CCT)に記録さ れたものであり（以下、CC̣Tに記録された反射強度 をCCTディジタル值と呼ぶ)、種々の分類アルゴリ ズムを通じて、水域系、裸地系 (田畑地・空地・荒 地・グランド等)、緑地系(針葉樹林・広葉樹林・野 草地)、市街地系(商業地・住宅地あるいは高・中・ 低密度市街地)などの土地被覆情報へ変換される。

人工衛星によるリモートセンシングの特徴は観測 の広域性・周期性であり、都市域のように土地被覆 の変化が著しい場所の最新情報の収集には最適であ る。都市水文への衛星デー夕の利用は、Ragan \&
Jackson（1975)がランドサット・データを用いて都 市河川流域の土地被覆を分類し、不浸透域の面積率 の推定について検討して以来、多くの研究者によっ て検討されている(Engman \& Gurney、1991)。

近年は、複数の人工衛星が地表面を観測している が、搭載されているセンサーの分解能はそれぞれ異 なっている。そこで本研究では、3つの人工衛星に よるリモートセンシング・データ(LANDSAT-MSS、 MOS-MESSR およびSPOT-HRV)を用いて、不浸透 域の面積比率の推定を検討することとした。すなわ ち、宮崎市小松川の流域 $4.64 \mathrm{~km}^{2}$ を解析対象に選ん で、まず1962年から1987年に撮影された航空写真を 目視で判読して、不浸透域の面積率を算定した。つ いで、3つの人工衛星によるリモートセンシング・ データから土地被覆情報を抽出し、これを利用して 不浸透面積率を推定するとともに、これらの值を航 空写真の判読結果と比較することによって、精度を 検討した。

な㧍、不浸透域の面積比率 (percentage of impervious area)の用語については、不浸透面積率(角屋、 1983)や不透水性面積率(新井ら、1987)など、研究 者によって異なって用いられているが、本論文では 不浸透面積率を用いることとした。また、従来の研 究では、市街地の土地被覆は商業地や住宅地などの 用途別に分類されているが、本来りモートセンシン グ・データが内蔵する情報は単に、地表面の電磁波 の反射特性という物理的特性であり、人間の活動に 基ついて定義される商業地あるいは業務地や住宅地 といった土地利用形態とは合致しにくいこと、さら に、本論で対象とする地域が雨水排水施設が設けら れないままに市街化した地域であるため、用途別の 分類は適当でないと判断して、高密度市街地・中密 度市街地・低密度市街地に分類することにした (Ragan \& Jackson、1980)。

リモートセンシング・データの土地被覆情報から の不浸透面積率の推定は 2 通りの方法を用いた。す なわち、(1)市街地 (高 · 中 ·低密度)への分類画素か ら直接的に推定する方法と、(2)各ゾーンの市街地 (高·中・低密度)への分類画素数の占有率を説明変 数とした重回帰式による推定方法について検討し た。 


\section{2. 解析方法}

\section{1 解析対象地域}

解析対象とした宮崎市の小松川流域のゾーン区分 を図ー 1 に示す。宮崎市の人口は約 29 万人であり、 市の中心を大淀川が流れている。小松川はその支川 であり、晴天時には本流の大淀川から合計 $1 \mathrm{~m}^{3} / \mathrm{s}$ の水量をポンプアップして水質維持を図っている典 型的な都市小河川である。流域は都心部の西に位置 し、県道(那珂・宮崎線)を東側分水界とし、西側の 大洗川に囲まれた南北に細長い形状になっている。

解析は、図一 1 に示すように下流から上流部へ延 長約 $3.5 \mathrm{~km}$ の範囲を対象とし、それを約 $500 \mathrm{~m}$ 毎に 7 区間に区切って、各区間を右岸・左岸に分けて計 14ゾーンとした。

\section{2 航空写真による不浸透域の判読}

表ー 1 に、目視判読に利用した航空写真の縮尺と 土地被覆分類に利用したリモートセンシング・デー

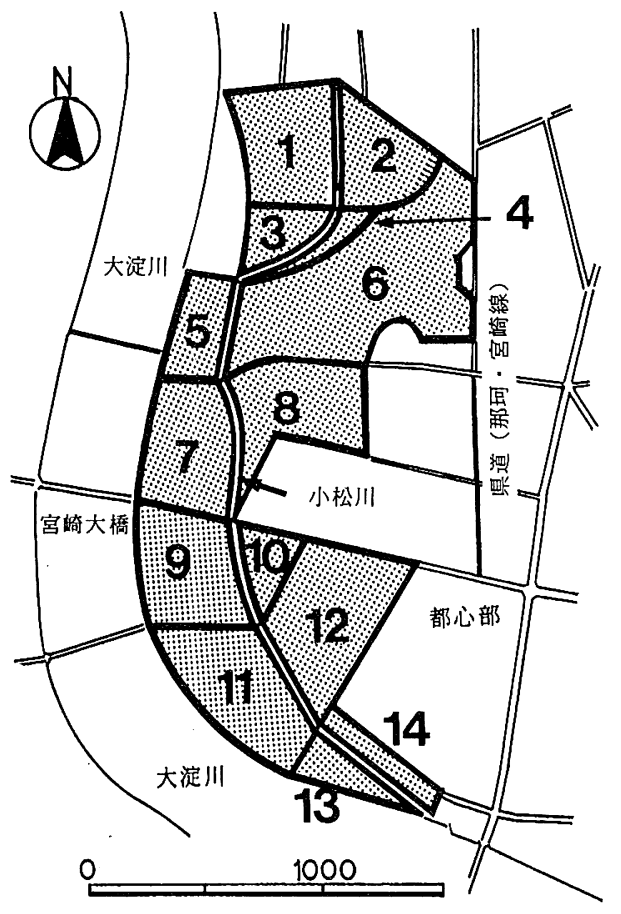

図一1 小松川流域と分割ゾーン

Fig.1 KOMATU watershed and devided zones for analysis
表ー1 不漫透域の判別に利用したデータ

Table 1 Imagery used for the classification of imperviousness

\begin{tabular}{l|c|c}
\hline 観测年 & 解 析データ & 縮尺・分解能 \\
\hline 1962 & 航空写真 (白黒) & $1 / 10,000$ \\
1966 & 航空写真 (白量) & $1 / 10,000$ \\
1971 & 航空写真 (白黒) & $1 / 23,000$ \\
1983 & 航空写真 (白黒) & $1 / 22.000$ \\
1984.10 & LANDSAT-MSS & $80 \mathrm{~m}$ \\
1987 & 航空写真 (力ラー) & $1 / 13.000$ \\
1988.10 & MOS-1-MESSR & $50 \mathrm{~m}$ \\
1988.12 & SPOT-1-HRV & $20 \mathrm{~m}$ \\
& ( CC CNES1988) & \\
\hline
\end{tabular}

夕の地上分解能(宇宙開発事業団、1987おうひびリモー トセンシング技術センター、1989)を示す。なお、 いずれのリモートセンシング・デー夕もバルク補正 済みのデータである。

解析では、まず航空写真を目視で判読することに よって不浸透域の面積を測定した。なお不浸透域は、 建築物・道路・駐車場などの人工構造物とし、浸透 域は森林・緑地・草地・公園・空地などとした。不 浸透域の判読および不浸透面積率の算定方法は以下 のとおりである(新井ほか、1987)。

まず、航空写真の上にアニメーション用の透明 フィルムを貼り、その上から不浸透域と判断される 人工構造物を黒く塗りつぶす。この際、白黒航空写 真の場合、矩形のものを建築物(住宅やアパート)に、 連続性のある白っぽい線を道路と判読した。ついで、 この方法で作成した白黒フィルムの上に $1 \mathrm{~mm}$ 目盛 りのトレース用方眼紙を固定し、1 マスに半分以上 黒が占める場合そのマスを黒く塗りつぶし、新たに 不浸透域と浸透域の白黑判別図を作成した。最後に、 この白黒判別図より、各ゾーンに対応する区画内の 黒マスの数を集計して、不浸透面積率を求めた。

これらの結果を図ー 2 に示す。眓から、この地域 においては1966年から1971年にかけて急激に都市化 が進行し、その後都市化の進行は鈍化してきている ことがわかる。また、1971年の航空写真では不浸透 域と目視判断された区画の中には、その後、浸透域 と判断されたものもあることが読み取れる。これは、 航空写真を用いた不浸透域の判別が簡単ではないこ とを示しており、特に白黒で小維尺の写真を用いる 場合には誤判読が含まれ易いと判断される。 


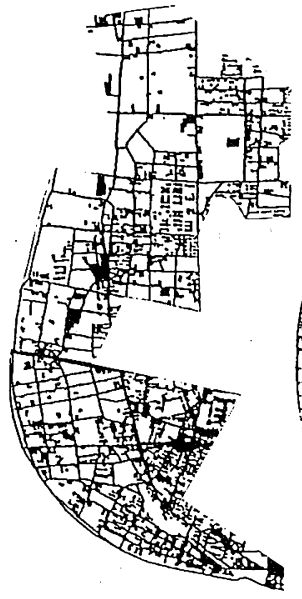

1962

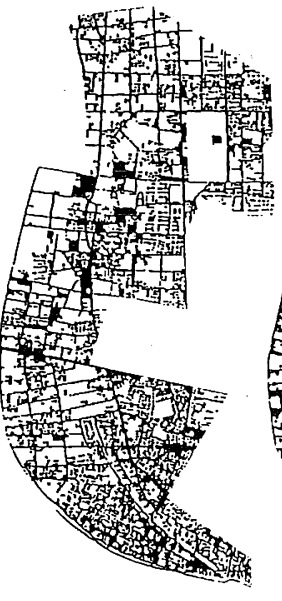

1966

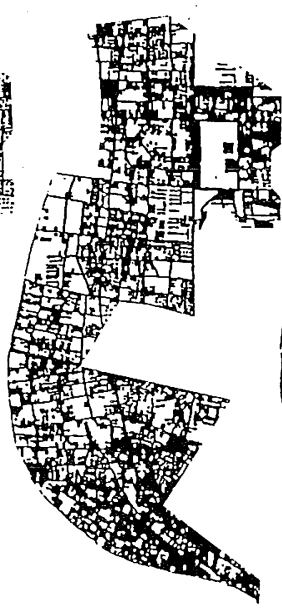

1971

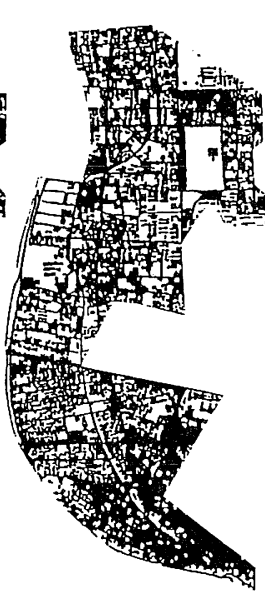

1983

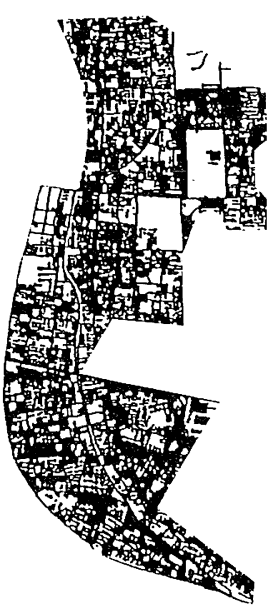

1987

図一2 航空写真から目視判読された不浸透域

Fig.2 Impervious areas manual-interpreted from aerial photographs

\section{3 人工衛星画像を利用した土地被覆分類}

リモートセンシング・データを用いた土地被覆分 類には様々な手法があるが、本論では 1 画素の CCTディジタル值を変量としたクラスタリング. アルゴリズムに基づいた手法を採用した。すなわち、 以下の方法で土地被覆分類を実施した。

1 )CCT から、座標変換式を用いて地形図に対応す るよう幾何学補正を施して、解析対象地域を包含す る地域の画像を切り出す。本論では、約 $10 \mathrm{~km}$ 四方 の地域とした(以下、この地域をサンプル地域と呼 ぶ)。

2 )この画像から200画素程度をサンプリングする。 これらサンプリングされた画素について、各バンド のCCT ディジタル值を変量としたウォード法によ りクラスター分析し、30個程度のクラスターを構成 する(以下、これらのクラスターを核クラスターと 呼灾)。

3 ) 核クラスターについて、各バンドを横軸に、 CCT ディジタル值を縦軸にとってグラフ表示した 分光特性図を出力する。

4 )これらの分光特性図の類似性を解析者が判断し て、他のクラスターに類似し、かつ構成画素が少な いクラスターを核クラスターから除外する。

5 )核クラスターの各バンドの CCT ディジタル值か ら計算されるユーグリッド距離を基準とした最近隣 法により、サンプル地域の画素を分類し、これをキャ
ラクターで表示した図面(以下、クラスター・マッ プと呼ぶ)を出力する。

6 )クラスター・マップと地形図や航空写真を比較 して、分類内容が確認できないクラスターは核クラ スターから除外する。

7 )満足する結果が得られるまで、5)、6)の手順を 繰り返し、最後に残った核クラスターを教師デー夕 として、最近隣法によりサンプル地域の土地被覆分 類を実施した。

本論では、この手順により、MSS、MESSR およ びSPOTデー夕に扔いて、それぞれ18、20、24個の 核クラスターが得られた。そこで、MSS、MESSR 拉よびSPOTデー夕間の分類結果、特に市街地に関 する分類結果の経時的な安定性をクラスター・マッ プで確認することによって、表ー 2 に示す分類項目 を設定した。な㧍、表の右欄は分類項目の核クラス ターの個数である。

このサンプル地域の土地被覆分類図から流域の各 ゾーンを認識するためには、ゾーンを閉じた領域と して認識することが必要になる。この方法は、2万 5 千分の 1 の地形図にゾーンの境界線を記入し、そ れをディジタイザーで読み取る方法(出口ほか、 1986)で行った。

図ー3は、この方法で作成した小松川流域の MESSR 画像による土地被覆分類図であり、市街地 以外の分類は “一”記号で表示した。キャラクター 


\section{表-2 人工衛星画像分類の土地被覆項目}

Table 2 Categories of land-cover defined for the classification of sattelite imagery

\begin{tabular}{c|c|l|c|c|c}
\hline \multirow{2}{*}{ 大分類 } & \multirow{2}{*}{ 小分類 } & \multirow{2}{*}{ 分 類 内 容 } & \multicolumn{3}{|c}{ 核クラスター 個数 } \\
\cline { 3 - 6 } & & & MSS & MESSR & SPOT \\
\hline \multirow{2}{*}{ 水域 } & 水域 & 海・池・川・影 & 1 & 2 & 2 \\
\cline { 2 - 6 } & 水際 & 水陸境界・干潟・影 & 1 & 1 & 1 \\
\hline 森林 & 森林 & 針葉樹・広葉樹・竹林 & 2 & 3 & 3 \\
\hline \multirow{3}{*}{ 空地 } & 裸地 & 運動場・造成地 (白色系) & 2 & 2 & 2 \\
\cline { 2 - 6 } & 野草地 & 草地・雑種地 & 2 & 2 & 4 \\
\cline { 2 - 6 } & 田畑地 & 田地・畑地 (茶色系) & 4 & 6 & 4 \\
\hline \multirow{3}{*}{ 市街地 } & 高密度 & 人工物が密集した市街地 & 2 & 2 & 3 \\
\cline { 2 - 6 } & 中密度 & 人工物・自然物の混交 & 2 & 1 & 2 \\
\cline { 2 - 6 } & 低密度 & 自然物が多い市街地 & 2 & 1 & 3 \\
\hline
\end{tabular}

で表示しているために若干見にくいが、市街地は前 出の図-2 の1987年の不浸透域と概ね対応している ことが読み取れる。なお、森林や野草地などの植生 に関する土地被覆情報は、浸透域の土壤など表土帯 の水分保留や地下水かん養に関する情報を内包して いると考えられ、興味ある事項であるが、本論の解 析は不浸透域のみを対象とした。

上記の方法で抽出した流域のリモートセンシン グ・デー夕には、土地被覆分類誤差の他に幾何学的 誤差、すなわち閉じた領域(ゾーン)を認識する際の 位置ずれが生じる。本論の場合、これは、(1)地形図 に対応するように画像を CCT から切り出す際に生 じる誤差と、(2)流域の各ゾーンを認識する際に生じ

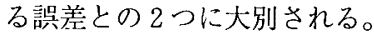

1 次の線形式の座標変換式の一つであるアフィン 変換式を使った場合、(1)の誤差は、概ね1.5画素程 度に収まる(出口ほか、1982)。一方、(2)の誤差は、 ユニバーサル横メルカトール座標などで数值化した 境界線を、リモートセンシング・デー夕の座標(ラ イン值、カラム值)に置き換えて認識する場合、必 然的に生じる。したがって、この誤差は画素の大き さ(地上分解能)とほぼ同一となり、ゾーンの面積が 狭い場合には相対的に大きくなる。

図ー4 は、ゾーンNo.11 と No.13の MSS土地 被覆分類図である。図中の網掛け部分で示したよう に、両ゾーンとも堤防に面した左縁および下縁から 1 画素から 2 画素程度、連続して野草地や田畑地に 分類されている。ところが、同じ境界線データを用 いて作成した前出の図一 3 の MESSR 土地被覆分類 図にはこれらの項目に対応する画素は見あたらな い。このことから、距離にして約 $100 \mathrm{~m}$ 程度のこの
$\& \% \% \& \&-\%$

$-\& \% \% \% \& \& \& \%-$

$\% \& \% \% \% \& \& \& \&$ \& - .

\& \& \& \% \% \& \% \% \& - . -

$\% \& \& \% \& \% \#-\%-\ldots-1$

$\# \% \% \& \& \% \%-8-\cdots$

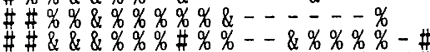

$\% \& \&-\% \% \% \% \# \#-\% \% \% \% \% \%$

\& \& \& \& \& \& \& \% \# \% \% \% \% \% \% \# \#

$\% \& \& \& \& \% \& \& \% \%-\% \% \% \% \% \%$ \#

\& \& \& $\% \% \% \% \%$

$\& \% \% \%-\% \% \%$

$\% \& \% \% \& \%-\% \& \% \ldots \% \%$

$-\% \% \% \% \%-\% \% \%$ - - $\% \% \% \% \%$

$\%$ \#\% \% \& \% \% \% \% - - $\%$ - \% \% \%

$-\% \% \% \# \% \% \& \% \% \& \% \% \% \%$

$-1 \%-\# \% \& \& \% \%--\% \% \%-\cdots$ $\%-\& \&-\# \# \&-\& \%+----\ldots \%$

$\%-\& \&-\#+\% \% \& \&-1 \%$ $-\%-\%-\% \% \% \%$

$\& \& \% \% \%$

$-\& \%$

\% $\%$ \% $\% \% \% \% \% \% \&--\& \%$

$-\% \% \# \% \% \# \% \% \# \% \& \%-\% \%$

- $\%$ \#\%\%\% \% $\%$ \#\% \& \% \% \& $\%$ \% \%

$--\% \& \& \% \% \# \# \% \% \%-\% \% \# \%$ \&

$\% \& \& \& \& \% \% \% \% \# \% \% \%--\& \# \# \#$

$\% \& \% \& \& \& \% \% \# \% \% \%---\% \%$

$\% \% \& \% \& \& \& \% \% \& \# \# \% \%-\% \% \% \#$

$\% \& \& \% \% \& \& \%-\& \% \%$

$\% \& \% \# \% \& \& \% \% \% \& \%$

$\% \# \# \# \# \% \%$

$\# \%$

\% $\%$ \% $\%$ \% $\%$

$\% \% \# \% \# \%$ \& \& \&

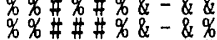

$\%$
$\& \%$$\%$ \# $\% \&-\& \%$

$\& \% \% \% \& \&-\% \# \#$

$\% \% \# \% \% \&-\% \% \% \%$

$-\% \% \% \% \% \% \& \& \% \% \% \% \% \%$

$\% \% \&-\% \% \% \& \&--\% \% \# \% \% \& \%$

$\& \&-\% \& \% \& \&--\% \% \% \#-\% \& \& \& \# \# \# \#$

\& $\% \%$ \% \& $\% \& \& \% \# \% \% \%$

$\% \%-\% \% \% \% \%-\% \# \# \#-\# \# \# \# \# \#$

$\% \% \& \% \& \# \% \% \% \% \# \# \# \#-\%$ \% $\%$ \% \# \#

$\% \% \& \% \& \% \# \# \%-\%-\# \% \% \% \# \# \%$

$\% \% \% \% \& \# \# \# \%-\% \% \%$. \#\#\% \% \%

$\% \# \%-\% \% \%-\%-8 \% \#-\% \% \%$

$\%$ \# $\% \% \%-\%-\& \% \#-\% \% \%$

- \#- \#\% $\%$ \%

$\%-\% \% \% \%$ \& $\%$ \%

$\% \% \% \% \% \% \# \# \# \% \%$

$\& \% \# \% \# \# \# \%-\# \%$ \&

$\%-\% \% \# \# \%-\# \% \%$

$\%-\%-\% \# \#-\frac{\pi}{*} \% \#$

$-\% \% \%$

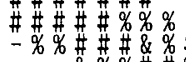

$\& \% \%$

図一 3 小松川流域の MESSR 土地被覆分類図

Fig.3 Land-cover map of KOMATU watershed classified from MESSR imagery

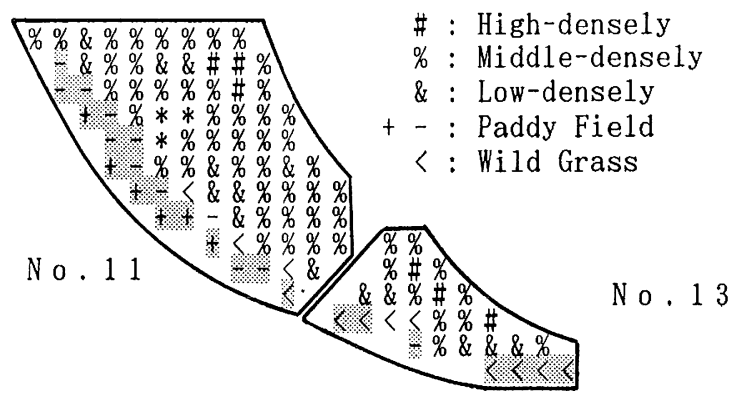

图ー4 ゾーンNo.11とNo.13の MSS 土地被覆分 類図

Fig.4 land-cover map of zone-11 and zone-13 classified from MSS imagery 
位置ずれは(1)の誤差に起因するものと判断される。 この種の誤差はリモートセンシング・データを利用 する場合、必ず生じるものであるが、実用に当たっ ては、画像データの切り出し時にグランド・コント ロール・ポイントを厳選すること、あるいは高次の 多項式を使って座標変換を行うことなどによって、 1 画素程度にまで小さくすることができるものと考 えられる。

\section{3. 解析結果と検討}

\section{1 航空写真判読による不浸透面積率}

表一 3 は、航空写真から判読した各ゾーンの不浸 透域面積率 (\%)の変化を示したものである。表から まず、対象地域全体の不浸透面積率が上記期間にお いて $42 \%$ から $77 \%$ に急增していることがわかる。ア ンダーラインは経年的に減少した值を表している。 表中、不浸透面積率が減少しているゾーンもあるが、 全体的な都市化の進行傾向と、2.2で述べた不浸透 域の算定方法を考慮すれば、これらの值は航空写真

\section{表ー 3 航空写真判読による不浸透面積率}

Table 3 Percentages of impervious area obtained by manual-intepretation of aerial photographs

\begin{tabular}{|c|c|c|}
\hline \multirow{2}{*}{ ゾーン } & 面積 & 不浸透面積率（％） \\
\hline & $\left(\mathrm{km}^{2}\right)$ & $\begin{array}{lllll}1962 & 1966 & 1971 & 1983 & 1987\end{array}$ \\
\hline 1 & 0.34 & $\begin{array}{lllll}11.8 & 22.5 & 70.8 & 75.7 & 83.3\end{array}$ \\
\hline 2 & 0.34 & $24.7 \quad 31.8 \quad 74.0 \quad 75.8 \quad 62.8$ \\
\hline 3 & 0.15 & $20.2 \quad 22.8 \quad 67.3 \quad 76.7 \overline{82.4}$ \\
\hline 4 & 0.09 & $\begin{array}{lllll}14.6 & 22.9 & 54.2 & 71.8 & 72.9\end{array}$ \\
\hline 5 & 0.23 & $\begin{array}{lllll}19.5 & 20.7 & 29.1 & 52.6 & 49.5\end{array}$ \\
\hline 6 & 0.88 & $41.0 \quad 43.4 \quad 67.7 \quad 67.7 \overline{67.2}$ \\
\hline 7 & 0.36 & $\begin{array}{llllll}34.3 & 40.3 & 69.7 & 71.1 & 77.7\end{array}$ \\
\hline 8 & 0.44 & $\begin{array}{lllll}54.9 & 46.5 & 75.9 & 79.5 & 81.7\end{array}$ \\
\hline 9 & 0.39 & $42.9 \overline{54.4} 66.980 .982 .5$ \\
\hline 10 & 0.13 & $\begin{array}{lllll}50.4 & 58.8 & 75.5 & 79.6 & 87.2\end{array}$ \\
\hline 11 & 0.44 & 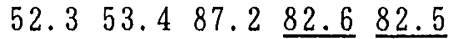 \\
\hline 12 & 0 . & $\begin{array}{llll}60.8 & 67.7 & 84.5 & 86.7 \quad 84.1\end{array}$ \\
\hline 13 & 0.14 & $\begin{array}{lllll}79.6 & 73.1 & 84.3 & 89.8 & 91.2\end{array}$ \\
\hline 14 & 0.13 & $\begin{array}{lllll}72.3 & 65.1 & 85.5 & 91.0 & 91.6\end{array}$ \\
\hline 全体 & 4.64 & $\begin{array}{lllll}41.9 & 45.3 & 72.0 & 76.2 & 76.6\end{array}$ \\
\hline
\end{tabular}

の誤判読と考えられ、その最大はゾーンNo. 8 に おいて約10\%程度になっている。現地調查からは、 このゾーンには大規模な施設も無いことが確認され ており、航空写真の目視判読においてはこの程度の 䛊差を生じるものと判断してよいものと考えられ る。

な㧍、ゾーンNo. 2の1987年の不浸透面積率の減 少については、宮崎大学農学部の移転に伴う校舎の 取り壊しによる減少であることが確認されている。

\section{2 人工衛星画像情報による不浸透面積率の直接的} 推定

ここでは1.で述べた(1)の方法、すなわち不浸透面 積率を、市街地(高・中・低密度)への分類画素から 直接的に推定した結果について述べる。な掞、1983 年と 1984 年 (MSS)、1987 年と 1988 年 (MESSR・ SPOT)のように、航空写真とリモートセンシング ・ デー夕の観測年にそれぞれ 1 年の差異があるが、以 下本論ではこれらを無視し、航空写真判読による不 浸透面積率を基準值として解析した。

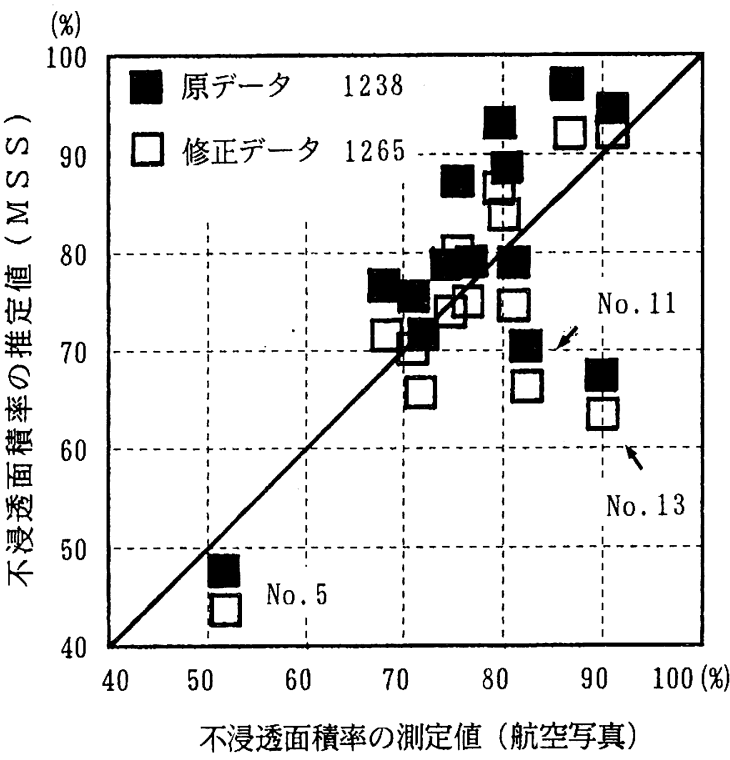

\section{図-5 航空写真判読と MSS 画像分類から推定し た不浸透面皘率の比較}

Fig.5 Comparison between the percentages of impervious areas derived from aerial photographs and the ones estimated from MSS imagery 

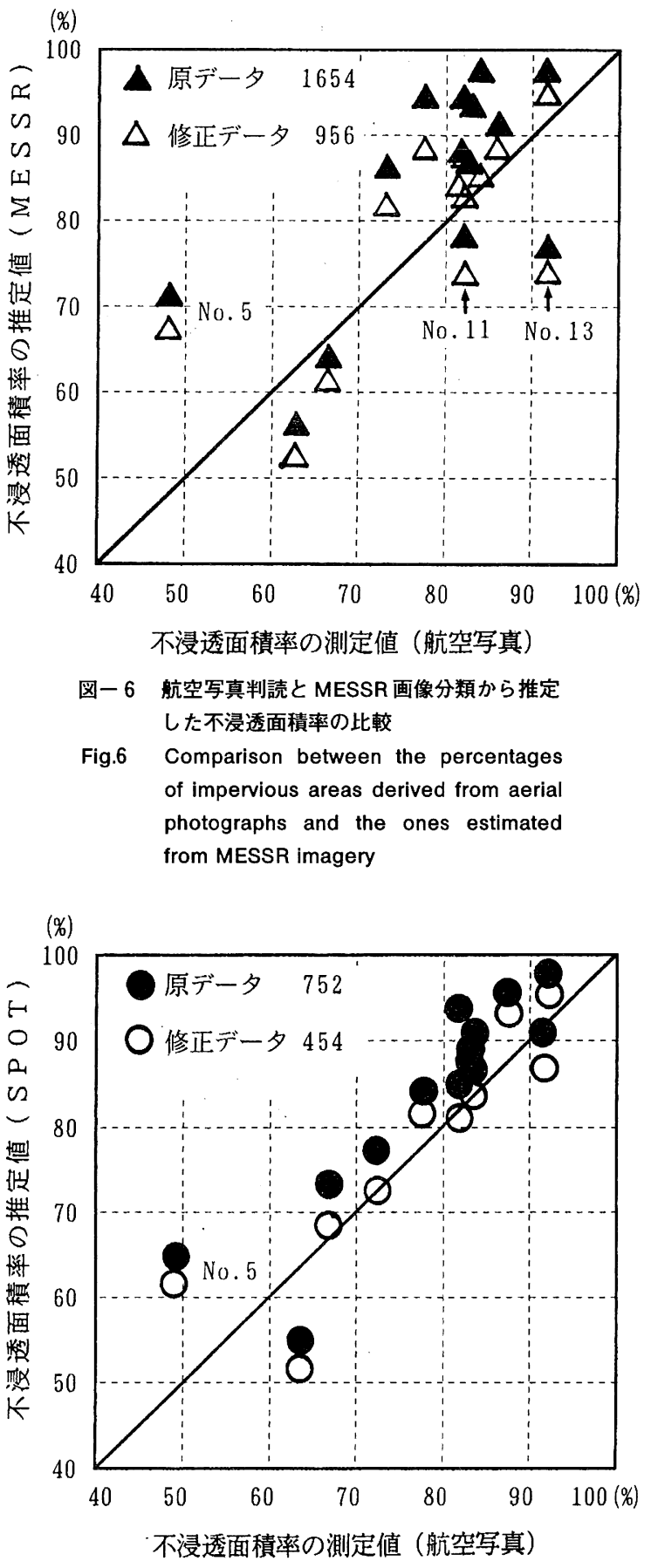

图-7 航空写真判読と SPOT 画像分類から推定 した不浸透面積率の比較

Fig.7 Comparison between the percentages of impervious areas derived from aerial photographs and the ones estimated from SPOT imaery
利用したリモートセンシング・データの地上分解 能は約 $80 \mathrm{~m} \sim 20 \mathrm{~m}$ であるため画素の多くはミクス チュアである。したがって、高密度市街地と判別・ 分類された画素にも空地や野草地などの浸透域が含 まれることになる。また逆に、空地や野草地と分類 された画素にも不浸透域が含まれている。

図一 5 は、航空写真判読により求めた不浸透面積 率の測定值とMSS土地被覆分類から推定した值に ついて、前者を横軸に、後者を縦軸にとって比較し たものである。ロ印で示した值は、高密度市街地・ 中密度市街地・低密度市街地と判別した画素の中が 全て不浸透域で占められると仮定して計算した値、 すなわち各ゾーンにおいて、高密度市街地・中密度 市街地・低密度市街地と判別した画素の数を、ゾー ン内の全画素数で除して求めた不浸透面積率であ り、ここでは原データと呼ぶことにする。

一方、口印は、高密度市街地 - 中密度市街地 - 低 密度市街地と判別された画素のうち、それぞれ $100 \% \cdot 95 \% \cdot 90 \%$ が不浸透域として修正・計算し た不浸透面積率であり、修正デー夕と呼ぶことにす る。また、図中の左上の凡例の横に記した数值は、 航空写真判読による測定値を基準值として計算した 残差 2 乗和である。以下、図一 6 および図 -7 も同 様である。

MSS およびMESSR と SPOT では若干の感知波長 帯域(バンド)の差異と、バンド数の差異(MSSおよ びMESSR は 4 バンド、SPOT は 3 バンド)の差異が あり、このため厳密には分類結果を詳細に検討する 必要があるが、これらの図と残差 2 乗和の值からみ れば、分解能が高くなるとともに推定精度も概ね上 がっている。またMSSの場合、原デー夕と修正デー 夕の残差 2 乗和の值には差異が見られないものの、 MESSR およびSPOT では修正データの值がかなり 小さくなり、推定精度が向上している。

な掞、上記の $100 \% \cdot 95 \% \cdot 90 \%$ の修正係数は、 以下の方法で決定した。すなわち、100\%・95\%・ $90 \% \cdot 85 \%$ の値からなる10組の係数を与えて不浸透 面積率を計算し、これと航空写真から得た不浸透面 積率から、残差 2 乗和を算出し、これを最小にした 係数を採用した。これらの修正係数の組み合わせと 残差 2 乗和の值を表一 4 に示す。なお、残差 2 乗和 はMSS、MESSR、SPOT の值の総計である。

表から、今回採用したCase-5の残差 2 乗和と Case-4およびCase-6の值の差異は、それほど大き 
表一 4 土地被覆情報の不浸透面積への修正係数と 残差 2 乗和

Table 4 Coefficient for transfroming the landcover to impervious area and residual sum of squares

\begin{tabular}{l|r|r|r|c}
\hline ケース & $\begin{array}{c}\text { 高密度 } \\
\text { 市街地 }\end{array}$ & $\begin{array}{r}\text { 中密度 } \\
\text { 市街地 }\end{array}$ & $\begin{array}{r}\text { 低密度 } \\
\text { 市街地 }\end{array}$ & $\begin{array}{c}\text { 残差 2 乗和 } \\
\text { の総計 }\end{array}$ \\
\hline Case- 1 & 100 & 100 & 100 & 3642 \\
Case- 2 & 100 & 100 & 95 & 3220 \\
Case- 3 & 100 & 95 & 95 & 2767 \\
Case- 4 & 95 & 95 & 95 & 2707 \\
Case-.5 & 100 & 95 & 90 & 2675 \\
Case- 6 & 95 & 95 & 90 & 2684 \\
Case- 7 & 95 & 90 & 90 & 2967 \\
Case- 8 & 95 & 90 & 85 & 3178 \\
Case- 9 & 90 & 90 & 85 & 3587 \\
Case-10 & 90 & 85 & 85 & 4606 \\
\hline
\end{tabular}

くはないことがわかる。修正係数の值は、設定した 土地被覆分類項目打よび対象地域の土地被覆状況に 関連し、また、表中の Case-4、Case-5、Case-6の 残差 2 乗和の差異から判断すれば、宮崎市と同程度 に都市化した他の地域に応用する場合、高密度市街 地については、100\%～95\%、低密度は95\%～90\% の範囲で変わる可能性があることを意味している。 したがって、今回得られた修正係数については、こ れらの修正係数を使って他の地域の不浸透面積率を 推定するなどして、妥当性を検証することが課題と して残る。

また、本推定法に関して、市街地を高密度市街地・ 中密度市街地 - 低密度市街地の 3 つの分類項目に分 ける意義については、表中の残差 2 乗和の值から判 断する限り、すなわち各分類項目の修正係数間に $5 \%$ の差異のあるCase-5(100\%・95\%・90\%) が 最小の残差 2 乗和を与えたという意味において、こ れを否定する結果は得られなかった。

\section{3 人工衛星画像情報による不浸透面積率の回帰} 推定

ここでは1.で述べた(2)の方法、すなわちゾーンの 市街地(高・中・低密度)への分類画素数の占有率を 説明变数とし、航空写真判読による不浸透面積率を 目的变数とした重回帰式によって不浸透面積率を推 定した。その際に得られたパラメータを表一 5 に示 す。表中、 $A_{1} 、 A_{2} 、 A_{3}$ は高・中・低密度市街地の

\section{表一 5 不浸透面皘率の重回帰分析結果}

Table 5 Results of multi-regression analysis for the percentages of impervious ares

\begin{tabular}{|c|c|c|c|c|c|c|}
\hline \multirow{2}{*}{ センサー } & \multicolumn{4}{|c|}{ 偏回帰 係 数 } & \multirow{2}{*}{$\begin{array}{l}\text { 重相関 } \\
\text { 係数 } \mathrm{R}\end{array}$} & \multirow{2}{*}{$\begin{array}{l}\text { 残 差 } \\
2 \text { 乗和 } \\
\end{array}$} \\
\hline & Ao & $A_{1}$ & $A_{2}$ & $A_{3}$ & & \\
\hline MSS & 47.1 & 0.75 & 0.35 & 0.37 & 0.74 & 561 \\
\hline MESSR & 31.0 & 0.83 & 0. & 0.63 & 0.81 & 589 \\
\hline SPOT & 20.5 & 0.77 & 0.72 & 0.49 & 0.91 & 313 \\
\hline
\end{tabular}

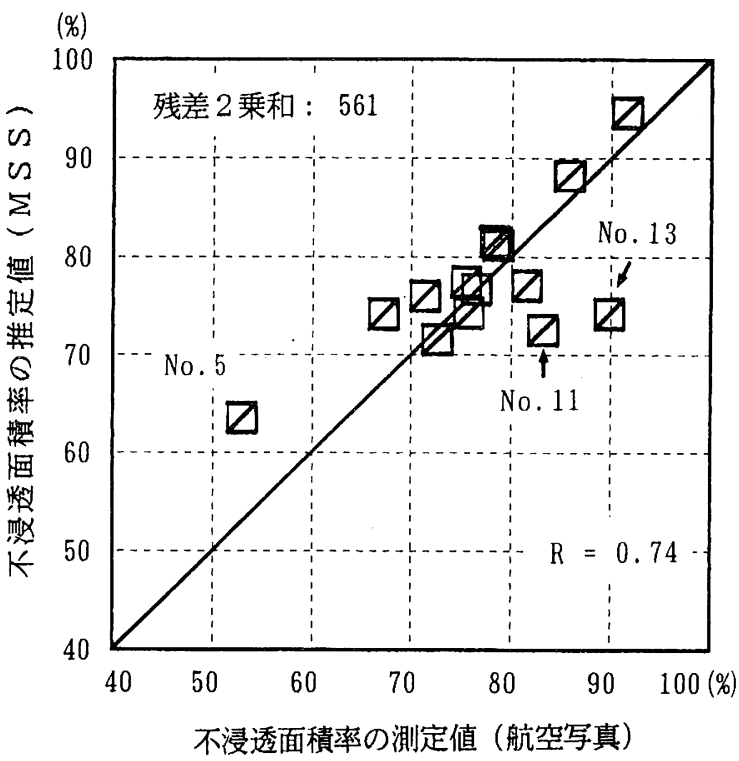

\section{図-8 航空写真判読と MSS 画像分類から重回帰} 推定した不浸透面積率の比較

Fig.8 Comparison between the percentages of impervious areas derived from aerial photographs and the ones estimated by multi-regression analysis using MSS imagery

偏回帰係数であり、 $\mathrm{A}_{0}$ は定数項である。サンプル 数が14と少ないため検討の余地は残るものの、重相 関係数はMSSでも 0.74 と比較的高く、またMSS $\rightarrow$ MESSR $\rightarrow$ SPOT と分解能が上がるにつれて向上して 扔り、この推定方法の妥当性が確認できる。

図一8、図ー9 および図-10は、航空写真判読に 上り求めた不浸透面積率の測定值と、この回帰手法 で推定した值について、前者を横軸に、後者を縦軸 にとって比較したものである。これらの図より、ゾー ンNo. 5 (MSS ・ MESSR・SPOT) 㧍よびNo. 11・ 


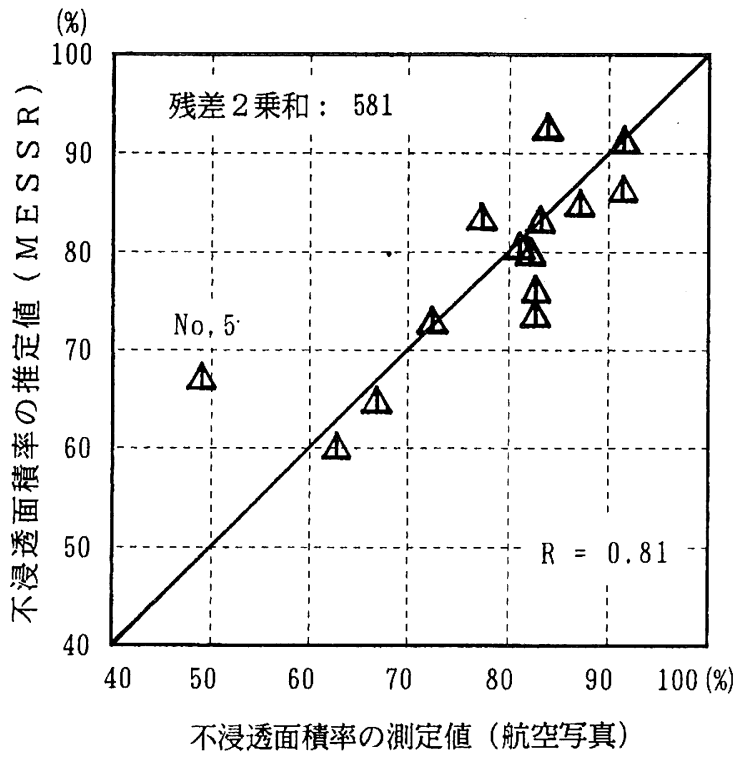

\section{园-9 航空写真判読と MESSR 画像分類から重回 帰推定した不浸透面皘率の比較}

Fig.9 Comparison between the percentages of impervious areas derived from aerial photographs and the ones estimated by multi-regression analysis using MESSR imagery

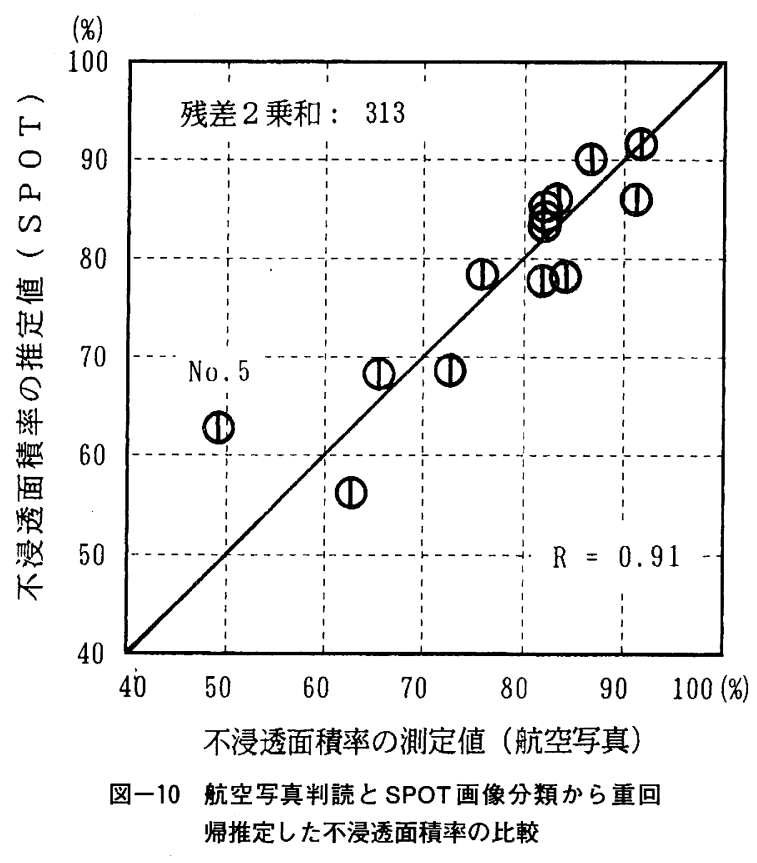

Fig.10 Comparison between the percentages of impervious areas derived from aerial photographs and the ones estimated by multi-regression analysis using SPOT imagery
No. 13(MSS) に扔いて大きい誤差が認められる。 それらの相対誤差の最大は、図ー8のゾーンNo. 13に打いて約 $16 \%$ 、図ー9 のゾーンNo.5に拈いて 約19\%、図ー10のゾーンNo.5において約13\%に なっている。

ゾーンNo. 11・No. 13は、前出の図ー4 に示し たように、今回のMSS 土地被覆分類は最大 2 画素 程度、野草地・田畑地(浸透域)に位置づれを生じて おり、したがって、これらのゾーンでは相対的に不 浸透域が過小評価されたことによるものと考えられ る。

ゾーンNo.5は、前出の表ー 3 で指摘したように 航空写真の結果にも誤判読があると考えられるこ と、さらにこのゾーンの大半は農林試験場の果樹園 であり、衛星画像による土地被覆分類の際に市街地 へ誤分類していることが考えられる。誤分類の理由 としては、教師データを作成するためのクラスター 分析を行う際に、サンプルデータを作成するが、都 市域では相対的に面積比率の小さい果樹園に該当す る画素がこのサンプルデータに含まれなかったこと によるものと考えられる。

以上、これらの 3 ゾーン以外は土10\%以下の相対 誤差に収まって㧍り、リモートセンシング・データ を利用することによって、航空写真利用の場合と同 等の精度で不浸透域面積率を推定できることが確認 できた。

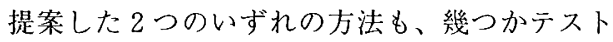
ゾーンを設定して推定結果を航空写真の判読結果な どで確認した後、解析対象地域全体へ拡大して不浸 透域面積率を推定する方法であるが、(1)の方法はサ ンプル数が少なくて済むという特長を持ち、更に都 市化の程度別に解析を重ねていくことにより、普遍 的な修正係数を算定できる可能性がある。一方、(2) の方法は、(1)の方法よりサンプル数が多く必要であ るが、統計的に推定精度を確認できるという利点が ある。したがって、今後はこれらの点に着目して解 析を進める必要があるものと考える。

\section{4. 結論}

本研究は、宮崎市小松川流域 $4.64 \mathrm{~km}^{2}$ を解析対象 として、人工衛星からのリモートセンシング・デー 夕から土地被覆情報を抽出し、これを利用して不浸 透面積率を推定するとともに、航空写真の判読結果 
と比較することによって推定精度を検討しだそるの 結果、航空写真を利用した場合と同じく概ね $10 \%$ 以 内の誤差で不浸透面積率を推定可能であり、その精 度はMSS $\rightarrow \mathrm{MESSR} \rightarrow \mathrm{SPOT}$ の順で高いことが確認で きた。リモートセンシング・データは、広域性・周 期性・解析の迅速性を特長とするものであり、地下 水かん養問題に対して利用できるものと考えられ る。

なお、解析に用いたLANDSAT (MSS)、MOS-1 (MESSR)およびSPOT(HRV)は、宇宙開発事業団地 球観測センターで受信・処理されたデータであり、 財団法人リモート・センシング技術センターを通じ て人手したものである。また解析には、本学学部生 の岩切洋昌君(現在、宮崎県) 掞よび岩崎敏彦君(現 在、大学院生)の協力を得た。ここに、記して謝意 を表します。

\section{参 考 論 文}

新井 正、新藤静夫、市川 新、吉越昭久(1987)：都市の 水文環境、共立出版、pp.10-14.

宇宙開発事業団(1987)：地球観測センターニュース、No.
21.

角屋 睦(1983): 新住宅地の不浸透面積率、京大防災年報、 26b-2、pp. 225-230.

出口近士、沼田 實、池上正春、横山 蕨(1982)：ランド サット・データの都市計画への適用一土地被覆分類一、 九州大学工学集報、Vol. 55、No. 6、 pp. 561-568.

出口近士、沼田 實、松尾和已(1986)：ランドサットMSS データの土地利用調查への適用に関する基礎的研究、日 本リモートセンシング学会誌、Vol. 6、No. 1、pp. 49-64. 虫明功臣、石崎勝義、吉野文雄、山口高志(1990): 水環境 の保全と再生、山海堂、pp. 27-54.

リモートセンシング技術センター(1989)：地球観測データ 利用ハンドブックーSPOT編一、pp. 1-1-4.

Draper, S. E. and Rao, S. G.(1986): Runoff Prediction Using Remote Sensing Imagery. Water Resource Bulletin 22, 941-9.

E.T. Engman and R. J. Gurney (1991): Remote Sensing in Hydrology. CHAPMAN AND HALL, pp. 107-109.

R. M. Ragan and T. J. Jackson (1975): Use of Satellite Data in Urban Hydrologic Models. Journal of the Hydrulics Division, ASCE, 101-HY12, pp. 1469-1475.

R. M. Ragan and T. J. Jackson (1980): Runoff Synthesis Using Landsat and SCS Model. Journal of the Hydrulics Division, ASCE, 106-HY5, pp. 667-678.

(受付：1992年 9 月 3 日、受理：1992年11月11日) 